\title{
PETRODIESEL WITH BIODIESEL WATER/OIL SEPARATOR FILTER - LOW PERFORMANCE
}

Sérgio Roberto Amaral ${ }^{1}$, José Luz Silveira ${ }^{2}$, Eloisa Couto Parkutz Costa ${ }^{3}$, Alan Baio Bonel $^{4}$, Thiago de Miranda Nogueira ${ }^{5}$, Marcos Marcondes Morin Cesar ${ }^{6}$, Marcio José Cirino $^{7}$

1Volkswagen Caminhões e Ônibus/IPBEN/UNESP - Laboratório Associado de Guaratinguetá/Universidade Estácio de Sá;

2IPBEN/UNESP - Laboratório Associado de Guaratinguetá;

3Universidade Estácio de Sá;

${ }^{4}$ Volkswagen Caminhões e Ônibus;

${ }^{5}$ Volkswagen Caminhões e Ônibus;

${ }^{6}$ TECCOM, Tecnologia em Combustão

${ }^{7}$ Parker Hannifin

sergio.amaral@volkswagen.com.br; joseluz@feg.unesp.br; e.parkutz@gmail.com; alan.bonel@volkswagen.com.br; Thiago.nogueira@volkswagen.com.br; mmarcondes@teccom10.com.br; marcio.cirino@parker.com

\begin{abstract}
The volume of pre filter sold during last five years have lead us to evaluate the root cause of it. Initially, it was verified the entire volume of pre filter commercialized increased 9 times from 2005 to 2018. The costumer's complaints are related to premature filter plugging and change interval under specification as informed by maintenance manual. Analysis have performed according to SAE J1839 and SAE J905 standards in order to evaluate water separation and filtering performance. It was confirmed a water separation performance reduced, including several cases near $60 \%$ with low mileages. Besides, it was noted sludge and wax at filtering media surface in umpteen samples. On the other hand, a comparison between field components - with commercial Diesel S10 B10 and diesel S10 B10 with high oxidation stability - was done and it was confirmed the filtering media life with high oxidation stability keeps the change interval according specification.
\end{abstract}


The trend with diesel S10 B15 with low and high stability was accomplished too. The media was analyzed with Scanner Electron Microscopy (SEM) in order to understand the influence of wax in water separation performance and effects in injector nozzle.

\section{Introduction}

According to Biodiesel Hand Book (2005) [2], the vegetable oils and animal fats were investigated as diesel fuels well before the energy crisis of 1970s. However, neat vegetable oils and animal fats are about 10 times more viscous than petrodiesel fuels, and they caused some operational and maintenance problems for diesel engines, so they were eventually abandoned as alternative diesel fuels. In Brazil, was started in 2005 with $2 \%$ in $\mathrm{v} / \mathrm{v}$ until the current $10 \%$ in 2019 . Some efforts to increase to $15 \%$ are on going and tests previewed to be done at end of this year. According Brian Sims (Biodiesel Magazine) [17], the use of petrodiesel and biodiesel blend has been practiced in many parts of the world for diesel engines. For example, since October 2005, B2 (B2 $=2$ vol \% biodiesel in diesel fuel) has become a mandatory use in Minnesota in most of the state's diesel fuel supply, in spite of a temporary snag due to the use of an off-spec biodiesel. "In August 2007, Minnesota governor Tim Pawlenty announced a plan requiring the state to increase its biodiesel mandate incrementally from B2 to B20 by 2015. The governor's proposal calls for Minnesota to move to B5 by 2008, B10 by 2011, B15 by 2013 and B20 by 2015". The American Filtration and Separation Society Conference (2008) affirm that the use of petrodiesel and biodiesel blend still causes some extent of concerns for the end users, especially when the ratio of the blend is increased from B2 to B20.

The Biodiesel Hand Book also inform that Biodiesel's storage stability, oxidative stability as well as its high affinity to dissolved water could lead to shortened fuel filter life and deteriorated fuel/water filtration efficiency. Biodiesel is known to have higher cloud point and more unsaturated hydrocarbon content, which tend to lead to earlier wax precipitation and increased intensity of fuel oxidation. The affinity to water is attributed to the more polar nature of alkyl-esters and unsaturated acids which barely exist in petrodiesel, a middistillate of crude oil with boiling temperature ranging from $180^{\circ} \mathrm{C}$ to $340^{\circ} \mathrm{C}$.

\section{1 - Volume of Pre Filter Sold}

Evaluating the volume of pre filter sold during 2005 to 2018 period and comparing the volume of biodiesel increased during those years. It was noted that the volume of pre filter commercialized increased according to percentage of biodiesel in v/v from $2 \%$ until $10 \%$. The graphic 1 show the volume sold trend according to volume of biodiesel increasing. 


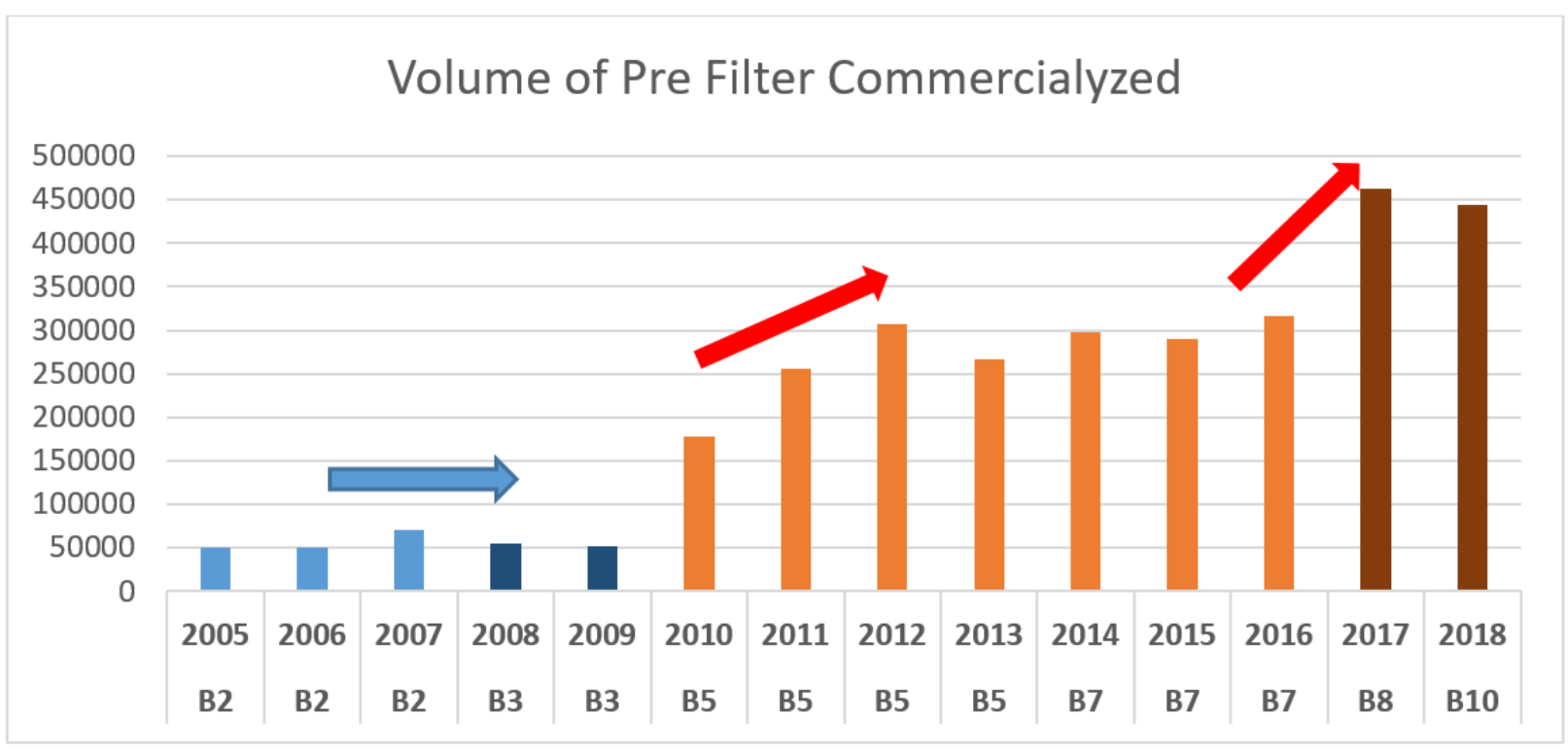

Graphic 1: Volume sold trend according to volume of biodiesel increasing (Source:

Parker Hannifin).

The volume sold increased 4,6 times (50.000/year to 230.000/year in average) from B3 in 2009 between period 2010-2016. The truck and bus production volume in Brazil increased in 2011 cause Euro 5 program (Proconve P7) and the aftermarket parts keeps the same trend until B7 in 2016. In 2017 new increment volume was noted when changed to $8 \% \mathrm{v} / \mathrm{v}$ and the volume of pre filter increased in $48,39 \%$. The Trucks and Buses field backlog and production volume from 2008 to 2017 does not match relating of total pre filter commercialized and specifically during Brazilian crisis period (2015 to 2018).

According to electronic magazine OTTO IN 2012 [1] the fuel contamination could be the responsible to cause some expensive and complex problems and in some cases could impact in water separation process. The Biodiesel Handbook [2] also inform that low oxidation stability reduce life and water/oil separation efficiency in diesel pre filter.

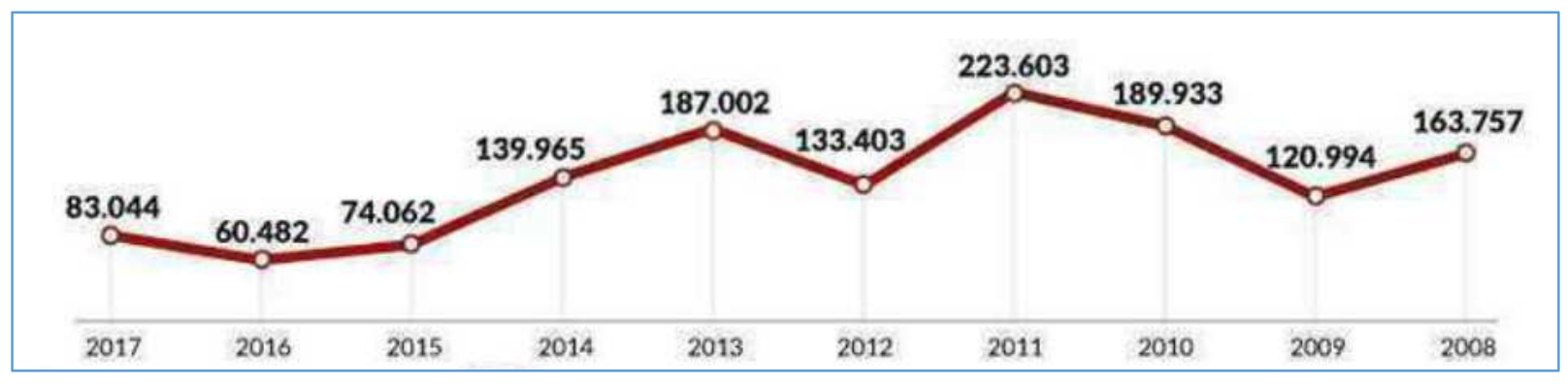

Graphic 2: Trucks volume production from 2008 to 2017 (Source: Anfavea).

\section{2 - Social, Economic and Environmental Analysis.}


The Energy and Mines Ministry (MME) informed in October 2016 [3], the trend reported in April of this same year through National Petroleum, Natural Gas and Biofuel Agency (ANP), if the investment to expand the national production of petrodiesel an biodiesel does not happens faster, it will be necessary to import around 24,6 billions of liters in 2030 in order to attend the diesel engine vehicles demand. The demand planned for 2016 is around 93,6 billions of petrodiesel liters included the $7 \%$ of biodiesel mixed (6,5 billion liters of biodiesel) than it is possible to conclude the production estimated demand of 18 billion liters of biodiesel could exceed at around 11,5 billion liters that correspond $47 \%$ of total importation. Certainly will contributes to increase at Brazilian Commercial Balance in a positive balance. The graphic 3 show the historic production, planting area and Brazilian soybean production between 2005 to 2015 according to CONAB [4]. It is verified the annual production growing in 5,7\%/year and the biodiesel production should be increased in order to support the demand in case of biodiesel mixed in petrodiesel increased as well.

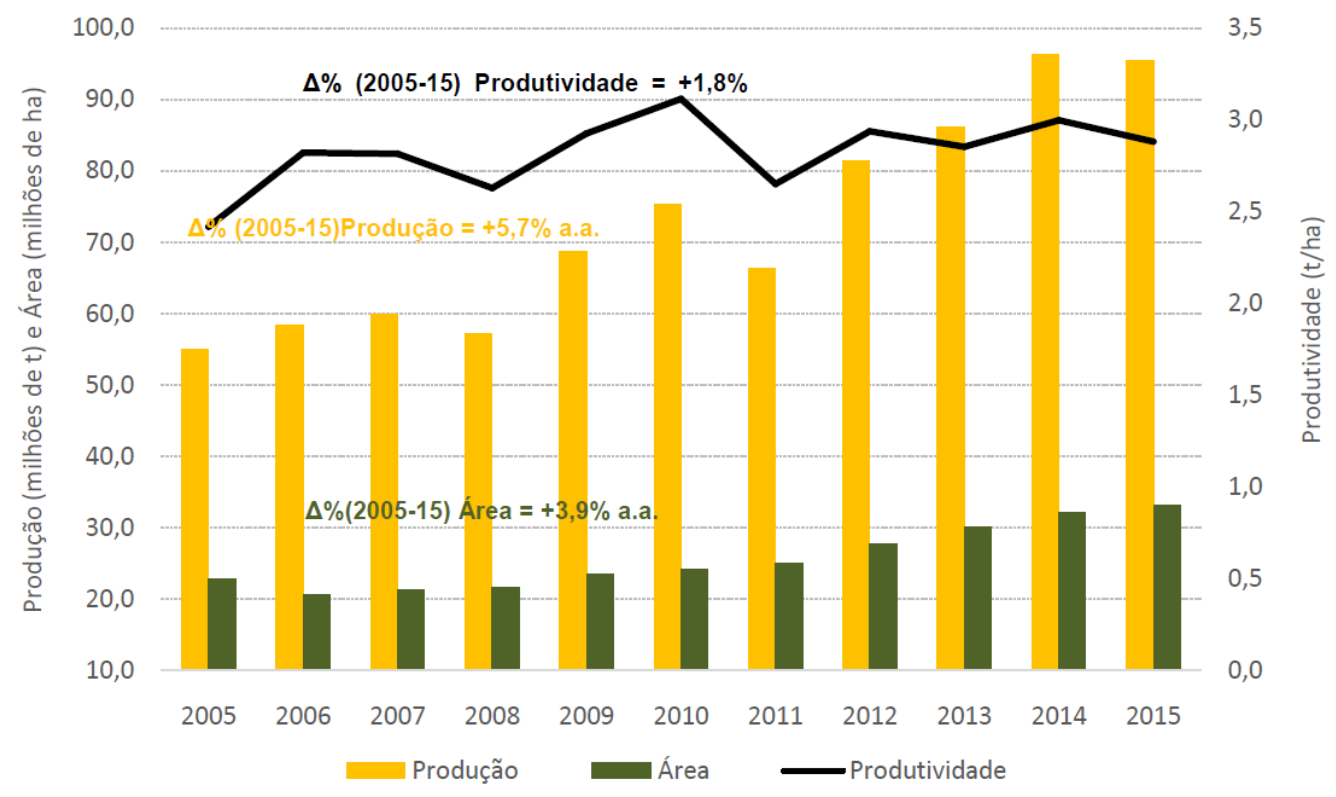

Graphic 3: Production historic, crop area and Brazil soybean production. Source: CONAB

The table 1 shows diesel consumption demand in Brazil increased. The soybean agribusiness production previewed between 2016 to 2030 increase in $300 \%$ and this growing condition bring some necessities as investments, employees generation, growth of cities, per capta incomes, facilities improvement by tax and cities investment. 


\begin{tabular}{lcccccc}
\hline Premissas/Projeções & $\mathbf{2 0 1 6}$ & $\mathbf{2 0 2 0}$ & $\mathbf{2 0 2 5}$ & $\mathbf{2 0 3 0}$ & $\begin{array}{c}\text { Unidade } \\
\text { (milhões) }\end{array}$ & $\begin{array}{c}\Delta \% \mathbf{2 0 1 6 - 3 0} \\
\text { (a.a.) }\end{array}$ \\
\hline \hline Mistura obrigatória & $\mathrm{B} 7$ & $\mathrm{~B} 10$ & $\mathrm{~B} 15$ & $\mathrm{~B} 20$ & $\%$ & - \\
Composição de matérias-primas & & & & & & - \\
$\quad$ Oleo de soja & 77 & 77 & 77 & 77 & $\%$ & - \\
$\quad$ Sebo bovino & 18 & 15 & 11 & 8 & $\%$ & - \\
$\quad$ Óleo de palma & 0 & 2 & 5 & 8 & $\%$ & - \\
$\quad$ Outros & 5 & 6 & 7 & 7 & $\%$ & - \\
Volume de diesel B & 55 & 64 & 76 & 90 & $\mathrm{~m}^{3}$ & $3,9 \%$ \\
Volume de biodiesel & 3,9 & 6,4 & 11,4 & 18,0 & $\mathrm{~m}^{3}$ & $12,6 \%$ \\
Volume de biodiesel de soja & 3,0 & 4,9 & 8,8 & 13,9 & $\mathrm{~m}^{3}$ & $12,6 \%$ \\
$\quad$ Óleo de soja para biodiesel & 2,6 & 4,3 & 7,7 & 12,2 & $\mathrm{t}$ & $12,6 \%$ \\
$\quad$ Soja processada para biodiesel & 14,1 & 23,4 & 41,8 & 65,9 & $\mathrm{t}$ & $12,6 \%$ \\
Volume de biodiesel de sebo bovino & 0,7 & 1,0 & 1,3 & 1,4 & $\mathrm{~m}^{3}$ & $5,8 \%$ \\
$\quad$ Sebo para biodiesel & 0,6 & 0,8 & 1,1 & 1,3 & $\mathrm{t}$ & $5,8 \%$ \\
$\quad$ Abates equivalentes & 27 & 37 & 48 & 55 & $\mathrm{cabeças}^{3}$ & $5,8 \%$ \\
Volume de biodiesel de óleo de palma & 0,0 & 0,1 & 0,6 & 1,4 & $\mathrm{~m}{ }^{3}$ & - \\
$\quad$ Óleo de palma para biodiesel & 0,0 & 0,1 & 0,5 & 1,3 & $\mathrm{t}$ & - \\
$\quad$ Área plantada necessária & 0,00 & 0,03 & 0,11 & 0,25 & $\mathrm{ha}$ & - \\
\hline \hline
\end{tabular}

Table 1. Raw material prediction for Biodiesel. Source: ABIOVE

The Management Center and Strategic Studies (CGEE) [5] from Science, Technology and Innovation Ministry (MCTI) 2004, soybean agribusiness estimative is the responsible to employ 4,7 million people direct and indirect in several areas as a production, transport, distribution, process and industrial raw material.

The Brazilian Company for Research and Agricultural (Embrapa) [6], inform that his production volume indicators for future is near to North American market. The United States production in 2017/2018 was 119,5 million of tons and in Brazil 117 million of tons and Gross National Income (PIB) indicator of agribusiness represent $20 \%$ of all Brazilian economic activity.

\section{3 - Special care for diesel pre filter water/oil separator scrap}

The "Meio Filtrante" magazine edition July/August 2007 [7] already present concerning about rightly filtering media scrap and the environmental responsibility must be required. According to the Meio Filtrante magazine, the main factor to be considered by legislation is the final disposal. The element disposal should be done by the waste generator responsibility and he should be done in right way avoiding possible environmental problem. In practice, the company that acquire and use the element media should disposal according current legislation.

Data from National Federation for the Distribution of Automotive Vehicles (FENABRAVE) [9] inform the total Truck and Bus Brazilian fleet is around 2,5 million of vehicles and the 
volume of pre filter replaced is 5 times/vehicle. According to Parker Hannifin company could produce diesel pre filter the current contaminated elements media annual volume represent around 10 million/year and the mass of by each one is around $1,2 \mathrm{~kg}$. In this way the total volume disposal per year is around 12.000 tons.

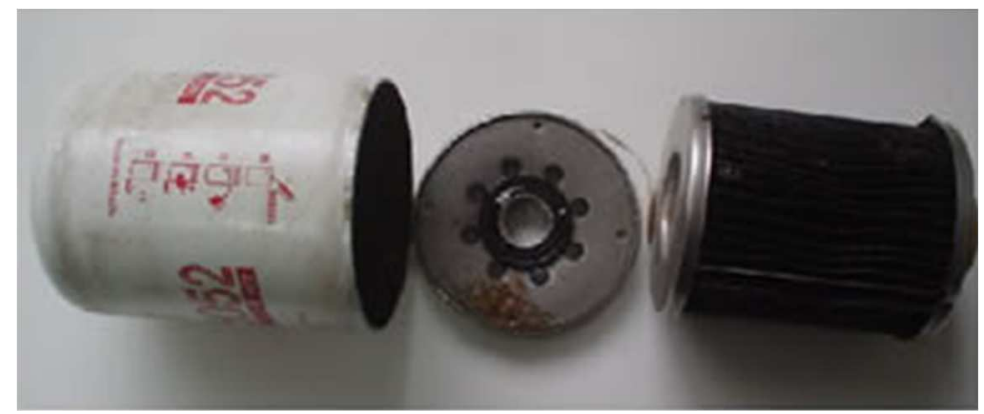

Image 1. Pre Filter water/oil separator disposal without right care. Source: Meio Filtrante Magazine, published in July/August 2012.

The Brazilian Association of Volkswagen Truck and Bus Distributors (ACAV) [10], request special attention for right disposal residues from Truck and Bus maintenance. The main materials identified are lubricant oil, oil filter, diesel filter (main and pre filter), air filter and tires.

The wrong destination could promote an environmental concern. In this way, the ACAV inform all Brazilian dealers to take care at those components disposal in order to avoid soil and water table contamination.

\section{4 - Pre filter engineering analysis.}

It was done several pre filter water/oil separation analysis at test bench, see image 2, with durability test parts and field parts. 


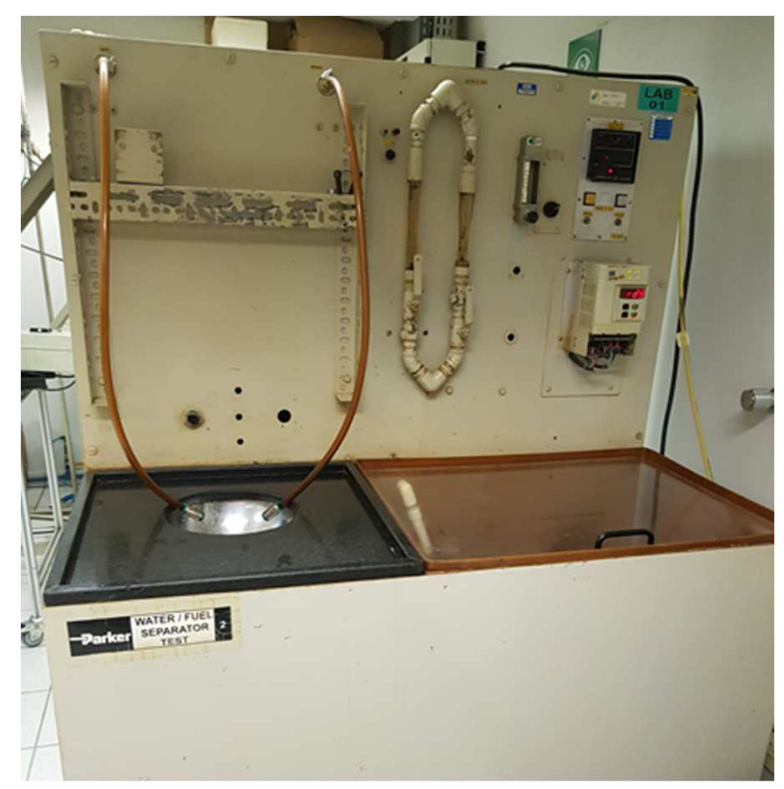

Image 2. Water separation test bench analysis according to SAE J1839. Source: Parker Hannifin

Were verify life performance difference regarding to water separation between pre filters with S10 B10, S500 B10 and S10 B15 with high and low oxidative stability. The main idea is linked at sludge formation during durability test according to high and low oxidation stability, reducing the water separation efficiency. Biodiesel is a hydroscopic fluid according to Biodiesel Handbook [2], the water could pass through the media element, in ppm, by mechanical drag and carried to injectors. This condition makes the injectors performance reduction. Vehicles with long period without engine start could reduce the oxidation stability and also the pre filter life. The injectors life reduction is a consequence of that.

Pre filter maker evaluate 221 parts from field claim and the previews information from dealers is fueled with S10 B10 only in all cases and the main claim is pre filter low performance. Customer replacement with $15.000 \mathrm{~km}$ in average and the normal service maintenance interval is around $60.000 \mathrm{~km}$ but depending of vehicle application could be around $40.000 \mathrm{~km}$. The oxidation stability according to Rancimat EN15751:2014 standard in average were 4 hours and the expectative is around 20 hours according to ANP resolution 30/2016. The lead time from diesel oil recovered and received for analysis could make the worse result. However the total lead time between costumer claim and analysis is 2 months in average. Than it can be considered a normal lead time for this kind of warranty analysis cycle.

All evaluation were done at test bench according to SAE J1839 standard for water separation performance and the results in average minimum ere $30 \%$. The minimum specification for approval is $95 \%$ and the supplier specification is $98 \%$ according to graphic 5. 


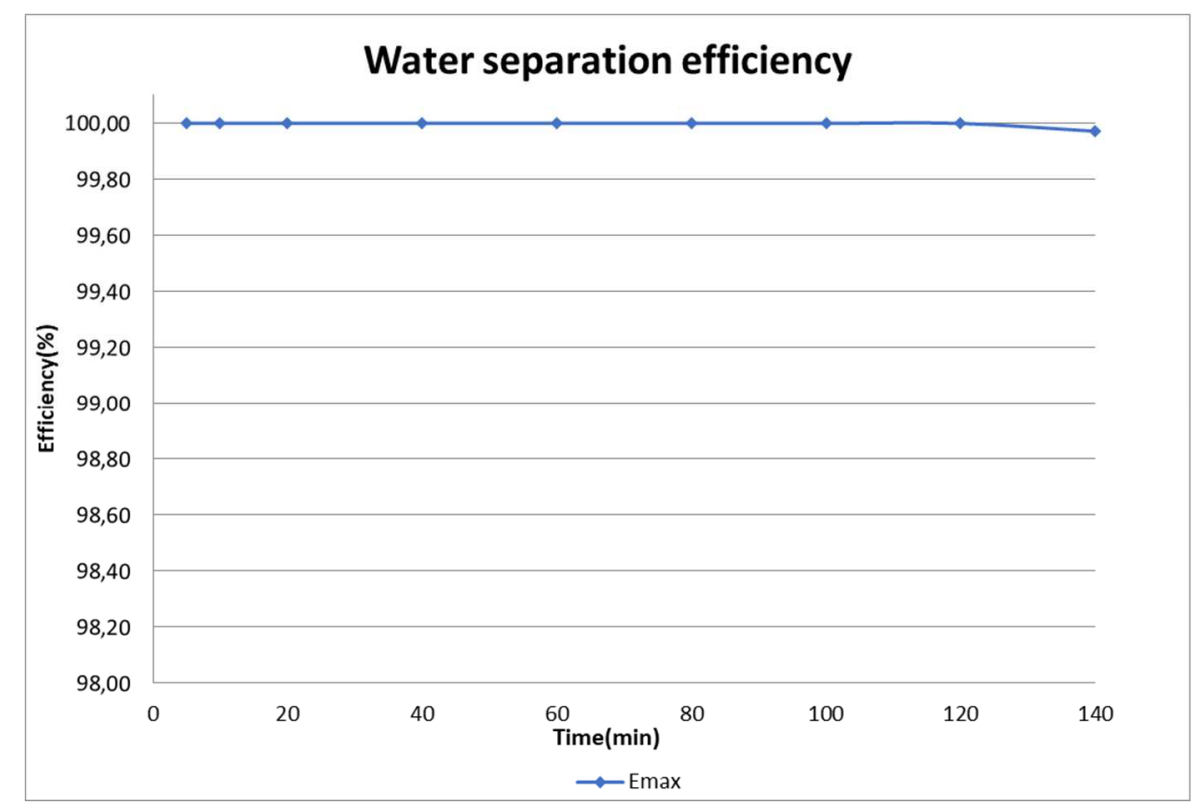

Graphic 5. Water separation efficiency - New element media. Source: Parker Hannifin. The SAE J1839 procedure as follows:

- Regular flow rate - $120 \mathrm{GPH}$;

- Add $18,9 \mathrm{ml} /$ minute of water at inlet filter side;

- Remove samples with $1 \mathrm{cc}$ at outlet filter side according intervals $5,10,15,20, \ldots$, 140 minutes.

- The efficiency is determined with Karl Fischer results.

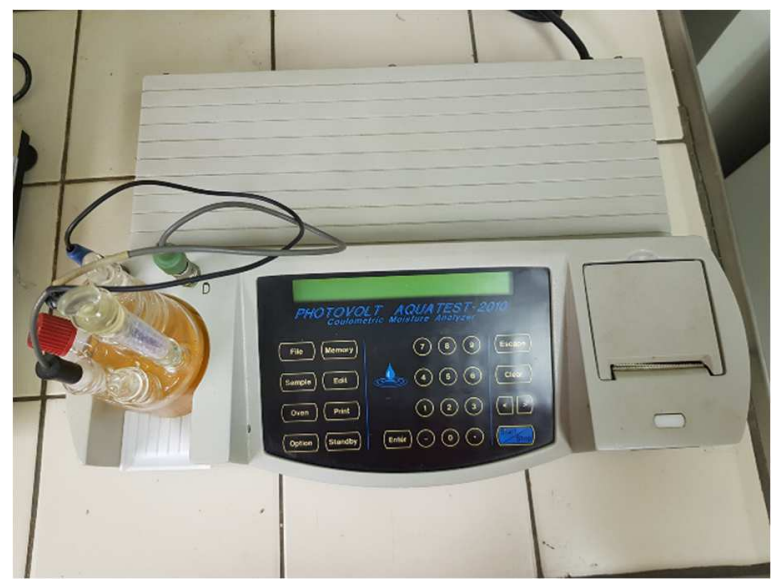

Image 3. Photovolt Aquatest 2010, Karl Fisher method. Source: Parker Hannifin

4.1 - Tests with S10 B10, S500 B10 and S10 B15 - High and Low Oxidation Stability.

Were tested 5 vehicles with Diesel S10 B10 and oxidation stability with 46 hours in average, according to Rancimat - DIN EN 15751:2004. The mileage tested in each 
vehicle is $40.000 \mathrm{~km}$ in average and the water separation performance found out was $90 \%$ in average, see image 4.

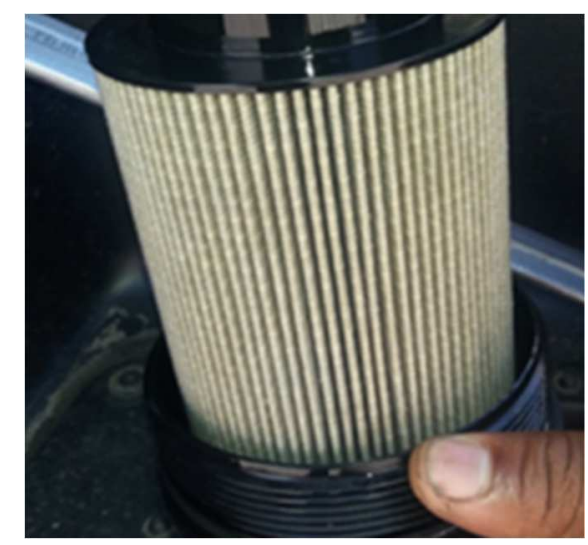

Image 4. Filtering element media after test with diesel S 10 B10 with 46 hours of oxidation stability. Water separation efficiency with $90 \%$ in average. Source: Volkswagen Truck \& Bus.

Were tested 5 vehicles with S 500 B10 and oxidation stability with 14 hours in average, according to Rancimat - DIN EN 15751:2004. The mileage tested in each vehicle was $30.000 \mathrm{~km}$ in average and the water separation performance found out was $50 \%$ in average, see image 5 .
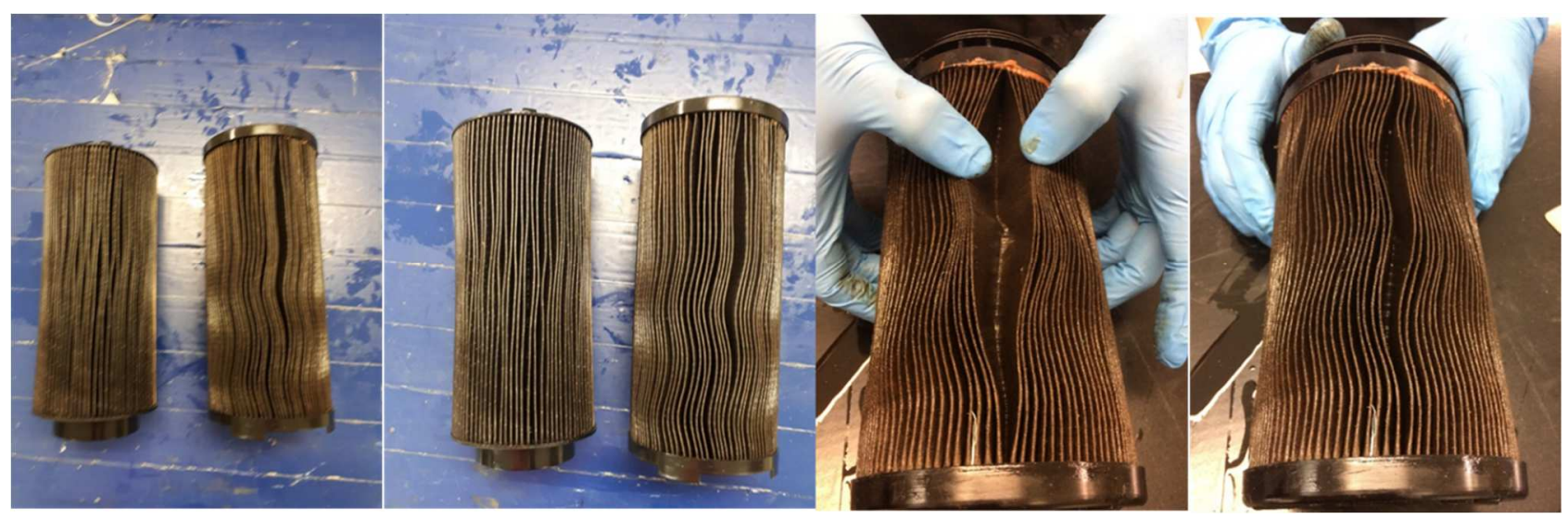

Image 5. Filtering element media after test with diesel S 500 B10 with 14 hours of oxidation stability. Water separation efficiency with $50 \%$ in average. Source: Volkswagen Truck \& Bus.

Were tested 1 vehicle with S10 B15 and oxidation stability with 4,5 hours, according to Rancimat - DIN EN 15751:2004. The mileage tested was $7.000 \mathrm{~km}$ and the water separation performance found out was 34\%, see image 6 . 


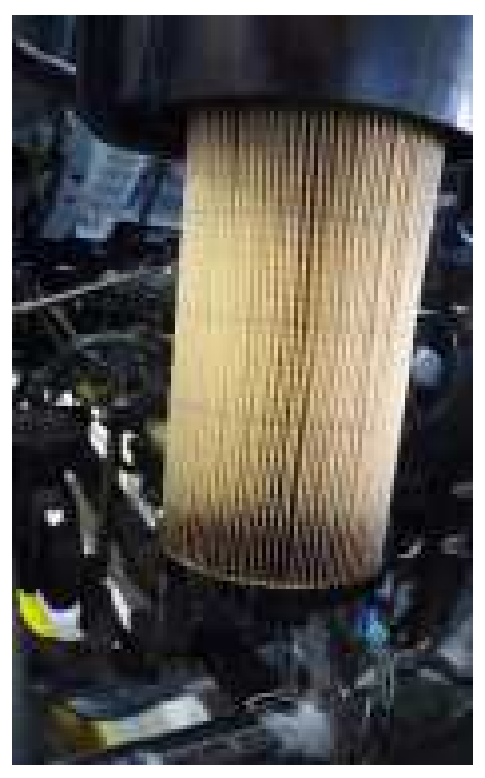

Image 6. Filtering element media after test with diesel S10 B15 with 4,5 hours of oxidation stability. Water separation efficiency with $34 \%$. Source: Volkswagen Truck \& Bus.

It was tested 1 vehicle with S10 B15 and oxidation stability with 27 hours, according to Rancimat - DIN EN 15751:2004. The mileage tested was $20.000 \mathrm{~km}$ and the water separation performance found out was $95,5 \%$, see image 7 .

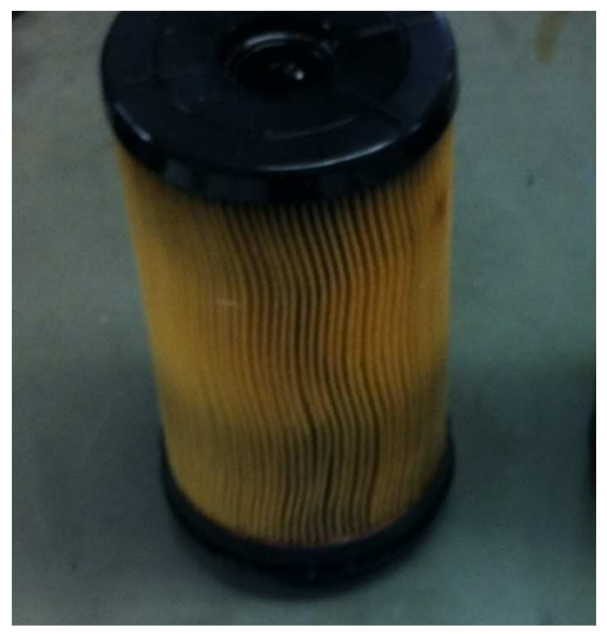

Image 7. Filtering element media after test with diesel S10 B15 with 27 hours of oxidation stability. Water separation efficiency with 95,5\%. Source: Volkswagen Truck \& Bus.

4.2 - Pre filter SEM analysis. 
It was decided to evaluate the element media at Scanner Electron Microscopy (SEM) in order to evaluate the fibers characteristics in a new media, tested in vehicle and keeping good water performance at test bench and tested in vehicle with low water separation performance at test bench.
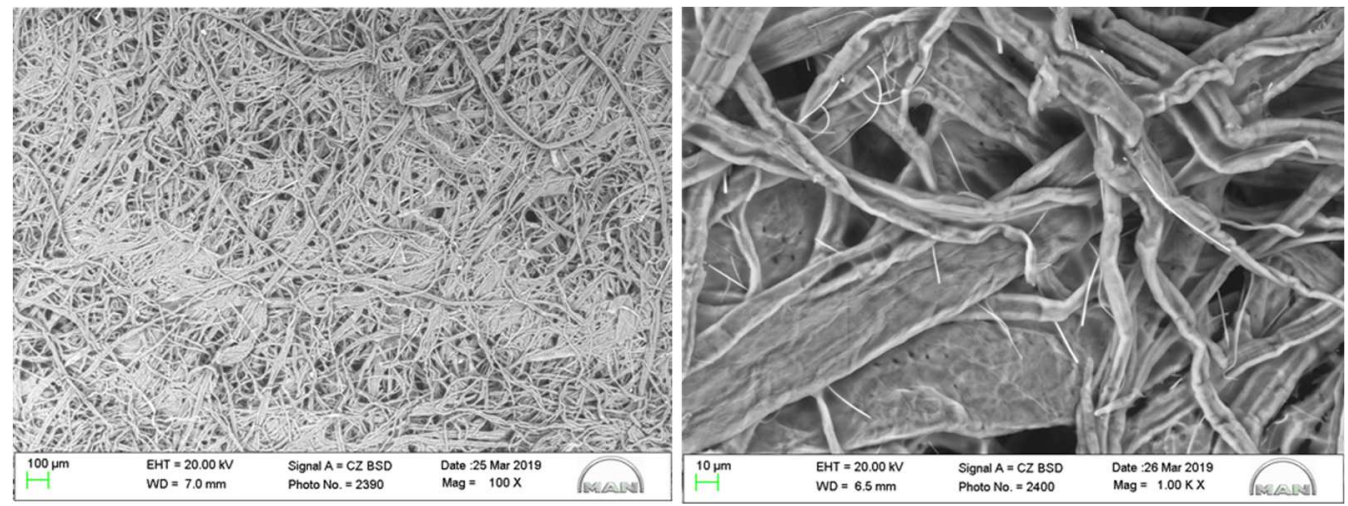

Image 8. New filtering element media 100X and 1000X. Source. Water separation efficiency with 98\%. Source: Volkswagen Truck \& Bus.
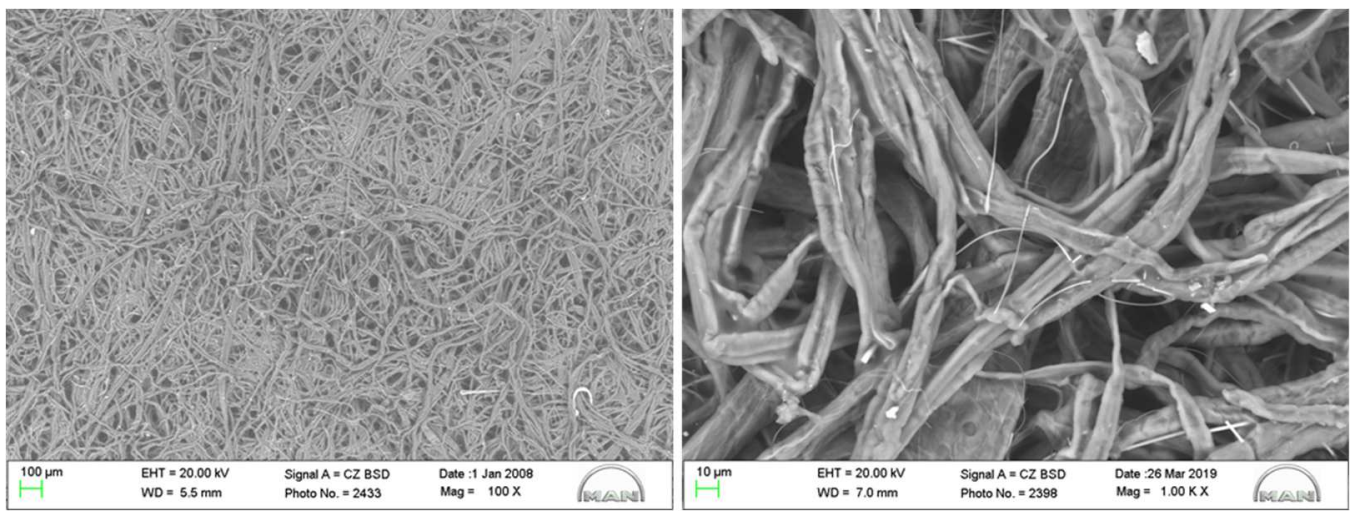

Image 9. Filtering element media tested with S10 B15 with 27 hours stability. Total tested: $20.000 \mathrm{~km}$. Imagens with: 100X and 1000X. Source. Water separation efficiency with 95,5\%. Source: Volkswagen Truck \& Bus.

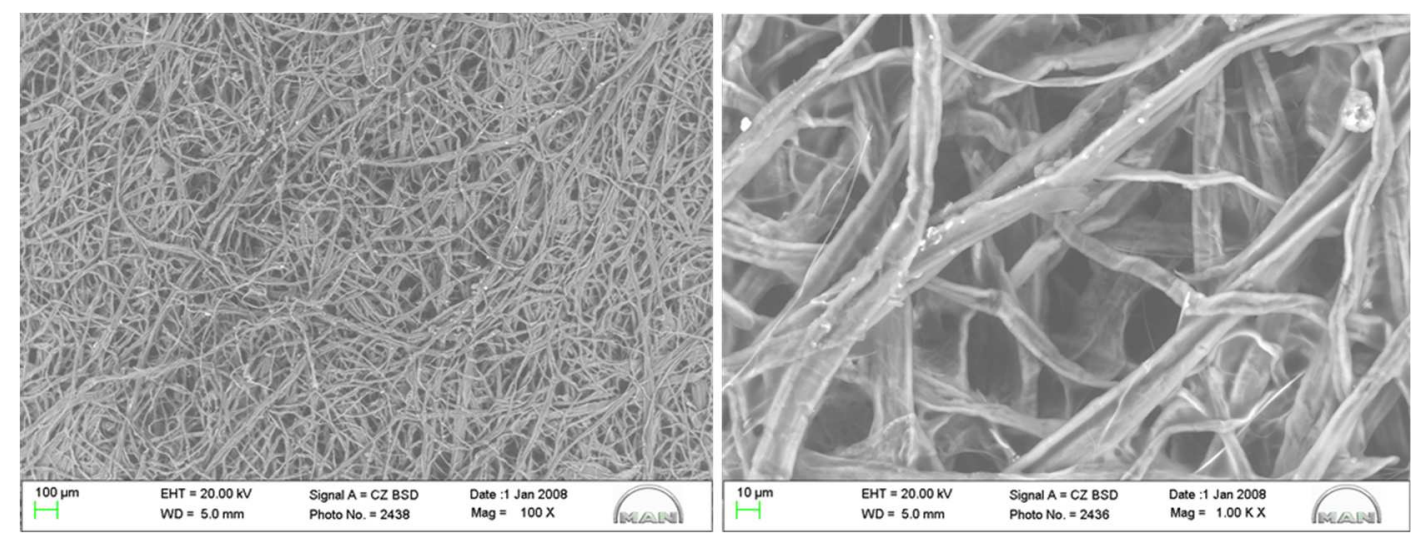


Image 10. Filtering element media tested with S10 B10 with 46 hours stability. Total tested: $73.000 \mathrm{~km}$. Imagens with: 100X and 1000X, Water separation efficiency with 65\%. Source: Volkswagen Truck \& Bus.

The element media showed at image 10 was replaced after pressure sensor send a replacement signal to the cluster. The analysis regarding water separation efficiency was $65 \%$.

\section{5 - Conclusion}

- The trend regarding the biodiesel percentage mixed at petrodiesel is a reality and this condition bring several economic and social benefits [9] to Brazil as an employment, per capta incomes and city tax collection increasing. The results could impact directly in education, health, safety and quality of life of inhabitants. Others aspects linked are transport, processing and biodiesel production are responsible for direct and indirect employment increase as well.

- The media filtering elements analysis evaluated with biodiesel oxidation stability over and lower than 20 hours shows a loss water/oil separation efficiency when the oxidation stability is lower than 20 hours. Then it will be necessary implement the 20 hours at Brazilian resolution as soon as possible. No other parameters were affected.

- It is necessary to include at National Policy of Solid Waste the diesel pre filter water/oil separator disposal in order to avoid water and soil contamination. The current Policy does not get this item defined.

- The National Policy of Solid Waste could include electrical energy by co generation with an opportunity.

- The analysis by SEM show the possible reduction of water separation as a result of biodiesel hygroscopic characteristic and the water goes through by mechanical drag. This condition reduces the water separation performance at filtering media with low mileage when the oxidation stability is low. With oxidation stability over 20 hours no water oil separations was noted.

6 - References

[1] OTTO Sistemas, A Importância do Filtro Separador Água/Óleo Diesel, http://www.ottosistemas.com.br/noticias.php?ler=Mzly: Access in Feb 02nd 2019

[2] KNOTHE, Gerhard; GERGEN, Jon Van; KRAHL, Jürgen. The Biodiesel Handbook, AOCS Press, Illinois, USA - 2005.

[3] BIODIESEL, OPORTUNIDADES E DESAFIOS A LONGO PRAZO- Associação Brasileira das Industrias de Óleos Vegetais - ABIOVE. Available 
at:http://www.abiove.org.br/site/ FILES/Portugues/07102016-131231-07 102016 ncenario para o biodiesel em 2030(2).pdf: Access in Mar 30 2019

[4] ACOMPANHAMENTO DA SAFRA BRASILEIRA DE GRÃOS - CONAB. Available at: https://www.conab.gov.br/info-agro/safras/graos: Access in Mar 03th 2019.

[5] CENTRO DE GESTÃO DE ESTUdOS ESTRATÉGICOS CGEE - Avaliação do Biodiesel no Brasil.

Available

at: https://www.cgee.org.br/documents/10195/734063/biocombustiveis1 4363.pdf/7042bda8-099541c4-9aaa-cd08c389315c?version=1.0 : Access in Mar 06th 2019

[6] EMPRESA BRASILEIRA DE PESQUISAS AGROPECUÁRIA, EMBRAPA, Relatório de Gestão Exercício 2017/2018. Available at: https://www.embrapa.br/documents/10180/1549626/Relatório+de+Gestão+2017/3181da5730f1-84a9-6292-916ae2170477 : Access in Mar 16th 2019.

[7] Descarte de Filtros Requer Cuidados Especiais. Available at: http://www.meiofiltrante.com.br/edicoes.asp?id=311\&link=ultima\&fase=C : Access in Fev 27th 2019

[8] SECRETARIA DE MEIO AMBENTE - SMA do Estado de São Paulo, Resolução SMA-038 de 02 de agosto de 2011. Available at: https://www.legisweb.com.br/legislacao/?id=170826. Access in Mar 3th 2019

[9] ANUÁRIO 2017 FENABRAVE - O Desempenho da Distribuição Automotiva no Brasil. Available

http://www3.fenabrave.org.br:8082/plus/modulos/listas/index.php?tac=indices-e-

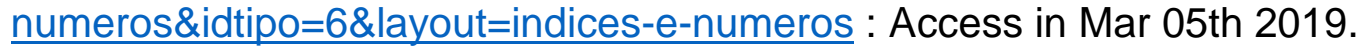

[10] ACAV dá Dicas Sobre Correto Descarte de Resíduos - Associação Brasileira de Distribuidores Volkswagen de Caminhões e Ônibus,. Available at: https://www.omecanico.com.br/acav-da-dicas-sobre-o-correto-descarte-de-residuos/. Access in Mar 05th 2019.

[11] CONSELHO NACIONAL DE MEIO AMBIENTE - CONAMA. RESOLUÇÃO CONAMA no 258, de 26 de agosto de 1999. Available at: http://www2.mma.gov.br/port/conama/legiabre.cfm?codlegi=258 : Access in Mar 05th 2019.

[12] CONSELHO NACIONAL DE MEIO AMBIENTE - CONAMA. RESOLUÇÃO CONAMA no 301, de 21 de março de 2002. Available at: http://www2.mma.gov.br/port/conama/legiabre.cfm?codlegi=364 : Access in Mar 05th 2019.

[13] CONSELHO NACIONAL DE MEIO AMBIENTE - CONAMA. RESOLUÇÃO No 357, DE 17 DE MARÇO DE 2005. Available at: 
http://www2.mma.gov.br/port/conama/legiabre.cfm?codlegi=459 : Access in Mar 05th 2019.

[14] CONSELHO NACIONAL DE MEIO AMBIENTE - CONAMA. RESOLUÇÃO CONAMA $\mathrm{n}^{\mathrm{o}} 362$, de 23 de junho de 2005. Available at: http://www2.mma.gov.br/port/conama/legiabre.cfm?codlegi=466 : Access in Mar 05th 2019.

[15] Efeitos da Produção de Biodiesel na Economia e no Emprego Formal na Agricultura. Available at: https://ainfo.cnptia.embrapa.br/digital/bitstream/item/109641/1/efeito-da-producaode-biodiesel.pdf : Access in Mar 27th 2019.

[16] DE LUCENA, Thomas Krisp: Impactos do Uso de Biodiesel na Economia Brasileira - Uma Análise do Modelo Insumo-Produto. Dissertação de Mestrado - UFF - RJ, 2008. Available at: http://www.ie.ufri.br/gema/pdfs/diss thomaslucena.pdf : Access in Mar 30th 2019.

[17] SIMS, Brian, Biodiesel Magazine. Available at: http://www.biodieselmagazine.com/authors/view/Bryan Sims. Access in Mar 10th 2019. 